\title{
THE IMPORTANT FACTORS OF TOURISM DEVELOPMENT IN SINGAPORE
}

\author{
Azhar Harun \\ University of Malaya, Kuala Lumpur Malaysia. Email: azharh@um.edu.my \\ Eko Suprayitno \\ University of Malaya, Kuala Lumpur, Malaysia and \\ Faculty of Economic and \\ Islamic State University Maulana Malik Ibrahim of Malang. \\ Email: ekonashwan@gmail.com; eko_prayitno457@yahoo.com
}

\begin{abstract}
This research paper will analyze the development of tourism industry in Singapore in which it focuses on the increasing number of tourist visit to Singapore, that contribute a significant source of tourism sector's income and its role to generate the Singapore's Gross Domestic Product (GDPS). The research aims to examine general characteristics of Singapore's tourism industry and its role within the process of globalization. By applying the theoretical explanations, this research will observe several main questions: How the tourist locates Singapore as a tourist place and how they enter Singapore. In addition, what are the possible consequences on Singapore especially the influence on its National Income? The field research has been conducted at the most popular location of tourist area. Three equations had formed the hypothesis to answer those questions. First, the output of the study has shown that the price of consumer index (Index) have influence the increasing number of tourist to Singapore (TouS) in a positive way. Second, there are many other factors that contributed to the tourism sector's income, however, the output of this study revealed only the total number of hotels in Singapore (HoS) is the major factors that contributed to the tourism sector's income (ImS).
\end{abstract}

Keywords: Tourism industry, Gross Domestic Product, Tourism sector income

Tourism industry becomes the popular sector for most of the developing countries in Southeast Asia e.g. Singapore, Malaysia, Thailand, Indonesia and Brunei. As in many Asian countries, the tourism industry has played a crucial role in the growth of Singapore's economy. This is because the tourism industry has the potential to generate foreign exchange earnings, create employment, promote development in various parts of the country, reduce income and employment disparities among regions, strengthen linkages among many sectors of the national economy and help to alleviate poverty. However, this standard view of the tourism industry does not give a complete picture of the potential 
contribution that tourism can provide for developing countries. Singapore is the one potential country that can develop the tourism sector to be the major sector. Tourism is fast becoming the most important sector for Singaporean economy. The number of tourists coming to Singapore has increased steadily, and in some years, spectacularly grown from 6.1 million in 2003 to 8.3 million in 2004 and 8.9 million in 2005 (Table 1).

Table 1 : The number of tourist and revenue from tourism sector in Singapore

\begin{tabular}{|r|r|r|}
\hline \multicolumn{1}{|l|}{ Year } & $\begin{array}{l}\text { Number of } \\
\text { Tourist } \\
\text { (million) }\end{array}$ & \multicolumn{1}{l|}{$\begin{array}{l}\text { Revenue } \\
\text { (million SD) }\end{array}$} \\
\hline 1995 & .00 & 7049.80 \\
1996 & 7292366 & 7350.00 \\
1997 & 7197871 & 6755.50 \\
1998 & 6242152 & 6207.40 \\
1999 & 6958201 & 5493.60 \\
2000 & 7691399 & 6033.30 \\
2001 & 7522163 & 6292.60 \\
2002 & 7567110 & 5699.30 \\
2003 & 6126569 & 5425.80 \\
2004 & 8328118 & 4315.60 \\
2005 & 8942408 & 4589.10 \\
& & \\
\hline
\end{tabular}

Source: Singapore Tourism Centre, 2005

The income accrued from tourism contributes substantially to the Singapore economy, now accounting for 11.4 percent of the country's GDP. This rate is higher than any other ASEAN country.

\section{The tourism sector development.}

From the statistic, tourism industry is Singapore has been on the upward trend for the pass years. Singaporean government has always been trying to promote this industry to generate more income for the country. Many promotional campaigns have been launched for both international and domestic tourists. A lot of money was and is allocated to improve the quality of Singaporean tourism products and services. For more success in tourism 
sector development, Singaporean Government have created a one agency that truly responsible in tourism sector namely "The Singapore Tourism Board (STB)". STB is an economic development agency for one of Singapore's key service sectors - tourism. The mission of the Board is to develop and champion tourism, so as to build the sector into a key driver of economic growth for Singapore. The Singapore Tourist Promotion Board was first established in 1964 with the mandate to promote Singapore as a tourist destination. The thinking of the government then was that an organization was needed to coordinate the efforts of hotels, airlines and travel agents in promoting the overall image of the destination.

With its strategic tourism units covering the key purposes of visit by tourists, the STB will work towards revitalizing traditional segments ranging from sightseeing and attractions to business travel, as well as actively tap into emerging segments such as healthcare and education services. These initiatives will be reinforced by STB's international operations which cover the key markets in Asia, Oceania, Europe and Americas, with expanded resources to capitalize on growth markets like China and India. STB's goal is to create exciting and innovative experiences for our visitors, in close partnership with the trade industry, thus etching forever in visitors' minds an image of Singapore as a unique and compelling destination. Singapore tourism industry has grown rapidly since STB was set up. In 2004, there were 8 million visitors. On 11 January 2005, Minister for Trade and Industry unveiled the Singapore Tourism Board's (STB) bold targets to doubling visitor arrivals to 17 million by 2015, see details here Tourism 2015.

Earlier in 1980, Singapore had made more money from tourism than from any other commercial activity, including industries's output export. However, by October 1987, a strong drop on visitors alarmed tourist officials. The cause would be one that is always linked to prostitution. Singapore is now suffering the consequences of fast growth in its tourism industry. Nevertheless, studies by Panvisavas and Taylor (2006) observed that the influences of foreign direct investment (FDI) applied in the use of management contracts and franchises have widespread as a form of booming the hotel business in Thailand and Singapore that catalyst the sector. Undoubtedly, through the efforts of both the Singapore government and the private sector, the number of international visitors and the amount of tourism-derived revenue has grown steadily.

Meanwhile, Sahadev and Islam (2005), expressing that most countries realized such rapid development and commercialization of information and communication technologies (ICTs) for the travel and tourism industry has also prompted hotels and other enterprises in 
tourism sector increasingly to adopt these technologies. This is based on the expectation that new ICT-based technologies and processes will lead to an improvement in operating efficiencies and customer service levels. According to Buhalis (1998) stated, that the trend rapid advances of adopting ICT technologies as well as the increasing demands of customers, has provide to those who look forward to flexible, specialized, accessible and interactive products and communication with principals. Hence, ICT-based products and processes help hotels to enhance operating efficiency and improve the service experience as well as providing a means to access markets on a global basis. Sahadev and Islam (2005a), also found the ICT with the establishment of e-commerce widely operated in the hotel industry, has been instrumental in helping the tourism sector to expand its markets across the continents and has played a major role in helping the growth of the industry. It seems at first that technology, monetary investment and such hotel management is ideal factor for the promotion of developing countries like Singapore and Thailand into the status of the world's top nations, there are consequences that accompany such change.

Within the incident of Asian economic downturn started in the summer of 1997 in Singapore, while Singapore Dollar fell by more than 20 percent in a month has directly led to a severe decline in tourism flow into and out of the region. Studied by Pine, et al. (1998) examines the impact of the Asian economic downturn on the hospitality and tourism industry then turns the sector player to review the region's hospitality trends and environments. The information has become the interest of hotel operators, governments, and research institutions. Most destinations in the region have been actively responding to the needs of several segments of tourist particularly business and Asian travelers, which then they enjoy longer holidays and have greater confidence in traveling on their own. The hotel operators mostly had modify their offerings wherever appropriate with the environment of target group's needs, while most luxury hotels in Asia transmit Japanese TV programs to guestrooms that attracts Japanese tourist. Increase in English language usage within and beyond the region has made independent traveling much easier.

\section{Potential improving the tourism sector}

Tourism is one of the industries that are generating considerable income for the country during the pass years. The advantage of Singapore to have many tourism places which support this industry and also the development of infrastructures can surely be the fuel to drive tourism industry further toward the excellence. Transportations are the gateway for people coming to the country. Air transportation serves us most in this case 
since Singapore is not located next to any major market. The largest portion of tourist has come through this gate way which means the development of it can benefit the country. The wave of Low Cost Airline (LCA) emergence is the sign saying that there will be more available seats to bring more visitors to Singapore. Also, the LCAs will tap in to the market where potential tourists are reluctant to come due to the cost of the airfare. LCAs will offer them the chance to travel with lower transportation cost, which mean it will be easier to decide to grab their luggage and fly to the country.

\section{Study Problem}

From the literature and data above, the total of tourist to visit Singapore in the last few years is very, in some year it has increase and another year it decrease. Hence the study problem can state from this issue as: What is the factor that influence the total number of tourist come to Singapore? In order to improve the tourism sector's income, what is the way that Singapore's government should invest? Which factor that can contribute to the tourism sector's income? Although, the Singaporean's government tries to invest heavily in tourism sector in the last few year, What will they got from these investment? So, Do the tourism sector contribute to the Singapore Gross Domestic Product (GDPS) ? And, from these investment (Singaporean Government's investment to the tourism sector), the study should highlight and discuss the profit, planning, policy, government expenditure and government's support to tourism sector and make a comparison with some countries in ASEAN. Which countries have implemented the good strategies and got more benefit from the investment?

\section{Objective of the Study and Methodology.}

\section{Objective of The Study :}

The research will analyze the development of tourism industry in Singapore in aspects of the increase of tourist number, the source of the tourism sector's income and its role in contribute to Gross Domestic Product. (GDP) of Singapore. The research aims at learning some general characteristics of the tourism, and linking them to theoretical explanations of tourism and its place in the process of globalization. The research main question is; how do the tourist knows Singapore and enter to visit Singapore? And what are the possible consequences for the receiving countries, in terms of income and cultural ? To answer these questions, The researcher have to do some field research in every part of tourism place in Singapore. The specific of the objective study can list bellows: 1)To analyses 
the factors that influence the increase of total number of tourist to Singapore, 2)To analyses the factors that contribute to the tourism sector's income, 3) To study the role of tourism sector in contribute to the Singapore Gross Domestic Product (GDPS).

\section{Methodology of The Study :}

This study utilized both the primary data collection and reference to the secondary data. For the primary data collection, a number of interviews have been conducted with various government agencies including officers from the Ministry of Tourism. Data were also gathered from foreign tourists visiting popular places or places of interests using random method. The secondary data collection involved library research on materials related to tourism industry in Singapore as well as overseas countries. It also entailed compiling data from The Singapore Tourism Board (STB) under the Ministry of Tourism, Singapore.

\section{Theory and Literature Reviews}

Hideki Imaoka, Muthi Semudram, Sahathavan Meyanathan and Kevin Chew (1990) has mention about the theory of Income Determination in the book "Models of the Malaysian Economy : A survey". The level of income (NNP) is determined without constraints from the supply side of the economy through demand components of macro aggregates: private consumption, government consumption, gross investment expenditure, change in inventory, exports and imports of goods, net receipts of factor and non-factor services, indirect tax and depreciation. Except for government consumption and change in inventory, all other demand components are treated as endogenous variables. Private consumption is disaggregated as follow: food, beverages and tobacco, household goods and services. Gross investment is broken down into building and construction, machinery and equipment, and agriculture. The export sector is disaggregated according to merchandise exports of manufactured goods, raw materials and other. Imports on the other hand, are broken down as follows: merchandise imports of the food, raw materials, machinery and equipment and manufactured goods. Desegregation of indirect tax revenue is according to indirect tax revenue from exports, imports and other sources. Each component of private consumption expenditure is explained by private disposable income $Y^{d}$ defined as :

$$
\mathrm{Y}^{\mathrm{d}}=\mathrm{NNP}-\mathrm{T}^{\mathrm{d}}+\mathrm{TR}
$$

Where $\quad$ NNP $=$ Net national product at factor cost

$\mathrm{T}^{\mathrm{d}} \quad=$ Direct Tax revenue from corporations and households 
$\mathrm{TR}=$ Current net transfer to households

The income multiplier process occupies a central role. However, the magnitude of the income multiplier is not reported. It can be expected that the income multiplier would be reduced to the extent that the marginal tax rate affects the marginal propensity to consume (Private). Also the indirect tax rate would affect the magnitude of the income multiplier through the marginal propensity to import. However, it is not possible to consistently calculate either the balanced or deficit budget income multiplier in the model as governmental budget constraint not specified in the model. The national income determined in the manner described above is then allocated to the agricultural and non-agricultural sectors. This is done through the following two equations.

$\mathrm{GDP}^{2}=\mathrm{f}\left[\left(\mathrm{GI}^{\mathrm{P}}+\mathrm{GI}^{\mathrm{b}}\right),\left(\mathrm{E}^{\mathrm{r}}+\mathrm{E}^{\mathrm{m}}+\mathrm{E}^{\mathrm{o}}\right),\left(\mathrm{M}^{\mathrm{P}}+\mathrm{M}^{\mathrm{f}}+\mathrm{M}^{\mathrm{r}}+\mathrm{M}^{\mathrm{m}}\right)\right]$
$\mathrm{GDPa}^{+}+\mathrm{GDP}^{\mathrm{n} a}=\mathrm{NNP}+\mathrm{DP}+\mathrm{SP}^{\mathrm{f}}+\mathrm{SR}^{\mathrm{f}}+\mathrm{T}^{\mathrm{e}}+\mathrm{T}^{\mathrm{m}}+\mathrm{T}^{\mathrm{o}}$

Where GDPna = gross domestic product of non-agricultural sector,

$\mathrm{GDPa}^{2}=$ gross domestic product of agricultural sector

$\mathrm{GI}^{\mathrm{P}}=$ gross investment in machinery and equipment

$\mathrm{GI}^{\mathrm{b}}=$ gross investment in building and construction

$\mathrm{E}^{\mathrm{r}}=$ merchandise exports of raw materials

$\mathrm{E}^{\mathrm{m}}=$ merchandise exports of manufactured goods

$\mathrm{E}^{\mathrm{o}}=$ merchandise exports of all other goods

$\mathrm{M}^{\mathrm{P}}=$ merchandise imports of machinery and equipment

$\mathrm{M}^{\mathrm{f}}=$ merchandise imports of food

$\mathrm{M}^{\mathrm{r}}=$ merchandise imports of raw materials

$\mathrm{M}^{\mathrm{m}}=$ merchandise imports of manufactured goods

$\mathrm{DP}=$ depreciation

$\mathrm{SP}^{\mathrm{f}}=$ payment for factor services

$\mathrm{SR}^{\mathrm{f}}$ = receipt from factor services

$\mathrm{Te}=$ indirect tax revenue from exports

$\mathrm{T}^{\mathrm{m}}=$ indirect tax revenue from imports

To $=$ indirect tax revenue from all other sources 
Tan Ka Eng (1986) discusses on the forecast Tourism in Malaysia in his paper on "A Study to Forecast Tourism Flow into Peninsular Malaysia Using Time Series Modeling Techniques'. Data source of the studies come from the interviewing Tourism agency as MOCAT officer, Tourism Development Centre (TDC) Report, Tourism Conference paper and the library. The objective of the studies tries to compare the forecast techniques on the total number of the tourist to visit Malaysia. He used Exponential Smoothing Method to discuss the forecast trend of the arrived of the tourist to Malaysia and to explain the relevance of the variable in his studies. Box-Jenkins Method also has took by him in being used and found it very impressive to make the short-term anxious technique in apply to the tourists arrived data. From the study, he found that the regression model is the most important and suitable in using to forecast the tourist arrival to Malaysia. But, the forecast of tourist arrival also depend to the independent variables.

The study of the tourism contribution to Malaysian economics has done by Lee Sin Yin (1993). The study aimed at testing the impact of tourism sector to manpower, the balance of payment, the tax revenues and the effect to the Malaysian GDP. Sources of the studies come from interview with the MOCAT officer and the LPPM Library. The studies found the tourism sector play a big role to contribute to the labor employment, balance of payment, to increase the national income per capita of people in Malaysia. Her study also touches on the increasing of hotel's manpower, total number of hotel's rooms because of the increase of tourist to Malaysia. From her studies, the tourists has increase from 2,250,509 tourists in 1980 to 3,100,906 tourists (1985) and 6,019,209 tourists in 1992.Its follow by the increasing in total number of hotel's rooms from 28,432 units (1980) to 35,720 units (1985) and 55,866 units in 1992. Lee Sin Yin also discuss on the Malaysian government's role to support the tourism sectors. The support that has done by the Malaysian government is to form The Tourism Development Center (TDC), to support the private sector to built the hotel, create the free zone from duty, gave permission to private sector to create tourism agency and to promoted the tourism destination to the world. From these activity, the tax revenues from the tourist arrival has increase from RM 4,652.55 million (1983) to RM 5,400.85 (1985) and RM 14,990.5 million in the year 1992.

\section{Model of The Study}

Based on the theory, literatures and study objectives, three hypotheses have been formulated. From the theory of Income Determination by Hideki Imaoka, Muthi Semudram, 
Sahathavan Meyanathan and Kevin Chew (1990), can be developed to the model of Singaporean Gross Domestic Product (GDPS), especially from the affect of the factor SRf or receipt from factor services to the GDPa. This model can be express on the affect of the tourism sector's income and industries sector's income to Singaporean Gross Domestic Product $[$ GDPS $=\mathrm{f}(\mathrm{ImS}$, IndusS)] as in no. 3. Tan Ka Eng (1986) gives us the idea to built tourist arrival model as in no. 1. And, from Lee Sin Yin (1993), we can form the tourism sector's income (ImS) as in the second model of this study. For easy understanding, these hypotheses are turned into functional form separating independent variables from the dependent variables. The empirical method used to test or analyze these hypotheses is that of multiple regressions. The three hypotheses, are as shown below: (1) The hypothesis about the total number of tourist to Singapore.

$$
\text { Tous }=\mathrm{f}(\text { Exch, Index })
$$

The hypothesis above aspect that the Singapore Exchange Rate (Exch) and Price Consumer Index (Index) has influence the increase of total number of tourist to Singapore (TouS), (2) The hypothesis of the tourism sector's income of Singapore.

$$
\mathrm{ImS}=\mathrm{f}(\mathrm{HoS}, \mathrm{TouS})
$$

The function of hypothesis above aspect that the total revenue of hotels in Singapore (HoS) and the number of tourists to Singapore (TouS) are the major factors that contributed to the Singaporean tourism sector's income (ImS).

(3) The hypothesis of the Singaporean Gross Domestic Product.

$$
\mathrm{GDPS}=\mathrm{f}(\mathrm{ImS}, \text { IndusS })
$$

The hypothesis above aspect that the Singaporean tourism sector's income (ImS) and the Thai Industries sector's income (IndusS) are the factors that influence Singaporean Gross Domestic Product (GDPS).

\section{Definition of The Variables}

TouS refer to the total of foreign Tourist who visit Singapore by the year from 1995 2004 (Million). Exch refer to the Singapore and US Dollars Exchange Rate by the year from 1995 - 2004 (Dollars Sin). Index is the Price Consumer Index in Singapore. Data will measure by consumer index from 1995-2004 (Sin Dollar). ImS is refer to the total Income from tourism sector in Singapore from 1995 - 2004 (Millions Dollars Sin). $\underline{\text { HoS }}$ are total Income of 
the hotel in Singapore from 1995-2004 (Millions Dollars Sin). GDPS is the Gross Domestic Product of Singapore from 1995 - 2004 (Millions Dollars Sin) and IndusS are refer to the total Income from the industries sector in Singapore from 1995 - 2004 (Million Dollars Sin).

\section{The Study Result}

The equation of total number of tourist to Singapore (TouS)

$$
\operatorname{Ln}(\text { TouS })=-7.073-0.730 \operatorname{Ln}(\text { Exch })+5.078 \operatorname{Ln}(\text { Index })^{* *}
$$

Note ** Significant at $95 \%$ level

$\begin{array}{ll}\text { R-Square } & =48.6 \% \\ \mathrm{~F}^{*} & =3.305 \\ \text { Significant F } & =90 \%\end{array}$

This equation tries to analyses the affect of the Singapore Exchange Rate (Exch) and Price Consumer Index (Index) to the total of tourist to visit Singapore (TouS). The independent variables as the Singapore Exchange Rate (Exch) and the Price Consumer Index (Index) are expect to influence the dependent variable, the total number of the tourist to visit Singapore (TouS). The output shows, only The price of consumer index (Index) are significant with the dependent variable (TouS), but the Singapore Exchange Rate (Exch) do not significant with TouS. The significant level of Index with TouS are 95\%. This output also shows R-Square and the F-test at the significant level. This output shown, when Index increase 1 unit, TouS will increase 5.078 units (Million). The stable of Price Consumer Index (Index) in Singapore will rage more tourists to visit Thailand. Although the Singapore Exchange Rate (Exch) decrease 1 unit will cause the variable TouS increase 0.730 unit, but the negative relation between Exch and TouS are not significant. This means that the decrease of Singapore Dollars do not influence to the total number of tourist to visit Singapore.

\section{The equation of tourist's sector income (ImS)}

$$
\begin{aligned}
\operatorname{ImS}= & 2401.802+4.418 \mathrm{HoS}^{* *}-0.0001616 \mathrm{TouS} \\
& (0.722) \quad(2.628) \\
\text { Note } \quad \text { ** } & \text { Significant at } 95 \% \text { level }
\end{aligned}
$$




$$
\begin{array}{ll}
\text { R-Square } & =60.8 \% \\
\mathrm{~F}^{*} & =5.437 \\
\text { Significant } \mathrm{F} & =95 \%
\end{array}
$$

This equation tries to analyses the affect of the hotels sector' income in Singapore (HoS) and the number of tourists to Singapore (TouS) to the Singaporean tourism sector's income (ImS). The independent variables like the hotels sector's income in Singapore (HoS) and the number of tourists to Singapore (TouS) are expect to influence the dependent variable like the tourist's sector income (ImS). The output shows, only the independent variable HoS is significant with the dependent variable (ImS). This output also shows that the F-test is significant and R-Square is very high. When HoS increase 1 unit, ImS will increase 4.418 units. The hotels sector's income in Singapore are very important sources to the Singapore Economy income. If the hotels sector's income increase by increasing of the room number of hotel or total number of hotel, it will lead to increase the tourism sector's income (ImS). Although TouS increase 1 unit and will cause the variable ImS decrease 0.0001616 unit, but the negative relation between TouS and ImS are not significant. This means that the number of tourists to Singapore (TouS) do not influence the tourism sector's income $(\operatorname{ImS})$. This result also shown although the total number of tourists decrease, it do not affect to the internal spending or the rotation of expenditures of the tourist.

\section{The equation of Singapore Gross Domestic Product (GDPS)}

$$
\begin{aligned}
& \text { GDPS }=145208.85-4.192 \mathrm{ImS}^{* *}+0.306 \text { IndusS } S^{* * *} \\
& (12.940) \quad(-3.117) \\
& \begin{array}{ll}
\text { R-Square } & =96.8 \% \\
\mathrm{~F}^{*} & =134.791
\end{array} \\
& \text { Significant F = } 99 \%
\end{aligned}
$$

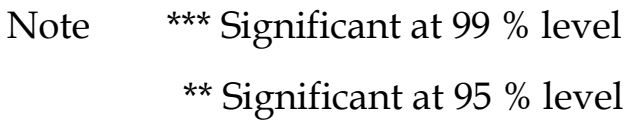


This equation tries to analyses the tourist's sector income (ImS) and the Industries sector's income (IndusS) to the Singapore's Gross Domestic Product (GDPS). The independent variables like the tourist's sector income (ImS) and the Industries sector's income (IndusS) are expect to influencing the dependent variable like the Singapore Gross Domestic Product (GDPS). This output shows that the F-test is significant and R-Square is very high and some relationship between variables from the outputs has support to the hypothesis. It shows; both independent variables [the tourist's sector income (ImS) and the Industries sector's income (IndusS)] are significant with the dependent variable (GDPS). When IndusS increase 1 unit, GDPS will increase 0.306 units and when ImS increase 1 unit, GDPS will decrease 4.192 units. The negative relationship between ImS and GDPS means, Although Singapore Government has promotes and supports the tourism industries, a lot of money was and is allocated to improve the quality of Singapore's tourism products and services. But the return of the tourism investment did not really support Singapore's Gross Domestic Product (GDPS). The government still need the big amount of money spent to the external and uncontrollable factors such as SARS, Bird Flu and terrorism situation around the world. This factors has come to obstruct the growth of GDPS in the recent year. After the hit of SARS and Bird Flu, number of tourism came to Singapore was drop by about 10 percent.

\section{Conclusion and Recommendations}

The output of the study shows only the price of consumer index (Index) is the major factor that influence the increase of total number of tourist to Singapore (TouS) in a positive way but not the Singapore Exchange Rate (Exch) In actuality, there are many factors that have contributed to the progress of the tourism sector's income; however the study shows only the hotels sector' income in Singapore (HoS) is the main factor that boasted to the tourism sector's income (ImS), but not the variable TouS (the number of tourists to Singapore). For the last equation, as depict by the outputs, it shows that in the early part of the development of Singapore economy, the industries sector played a big role in contributing to the Singaporean Gross Domestic Product (GDPS), not the tourism sector's income (ImS). However, under the present policy, the government still make efforts to invest more in this sector based on the new budget allocation recognizing the importance of the tourism sector as one of the most important industry contributing to the Singaporean Gross Domestic Product (GDPS) in the next few years. In the other side of this study, the output shown that the large number of tourist will be created more culture and social 
problem to the local Singaporean society. To increase the total number of tourist to Singapore (TouS), Singaporean Tourism's sector income (ImS) and the Singaporean Gross Domestic Product (GDPS), Singaporean government should take seriously on tourism sector in context of investment and development. This is because the tourism sector will integrates a wide range of economic activities and is now regarded as one of the world's largest industries. 


\section{BIBLIOGRAPHY}

Lee Sin Yan. 1993. Sumbangan pelancongan kepada ekonomi Negara (The tourism contribution to Malaysian economics), Master of Economics Theses. Kuala Lumpur: University of Malaya.

Tan Ka Eng. 1986. A Study to Forecast Tourism Flow into Peninsular Malaysia Using Time Series Modeling Techniques. Master of Economics Theses. Kuala Lumpur: University of Malaya.

Hideki Imaoka, Muthi Semudram, Sahathavan Meyanathan and Kevin Chew. 1990. Models of the Malaysian Economy : A survey, Malaysian Institute of Economic Research. First Edition. Malaysia: National Bank, Kuala Lumpur.

Buhalis, D. 1998. "Strategic use of information technologies in the tourism industry", Tourism Management, Vol. 19, pp. 409-21.

Singapore Tourism Centre. 2005. Statistical Report 2002-2005. Singapore: The Singapore Tourism Board (STB).

Panvisavas, V and Taylor, J.S. 2006. "The use of management contracts by international hotel firms in Thailand". International Journal of Contemporary Hospitality Management. Vol. 18, No.3, pp. 231-245.

Sahadev, S. and Islam, N. 2005. "Why hotels adopt ICTs: a study on the ICT adoption propensity of hotels in Thailand". International Journal of Contemporary Hospitality Management. Vol. 17, No. 5, pp. 391-401

Sahadev, S. and Islam, N. 2005a. "Exploring the determinants of e-commerce usage in the hotel industry in Thailand: An Empirical Study". Information Technology \& Tourism, Vol. 7 pp. 000-010. 